\title{
Herpes Zoster Ophthalmicus in a Patient with Systemic Lupus Erythematosus and Antiphospholipid Syndrome
}

\author{
Sistemik Lupus Eritematöz ve Antifosfolipid Sendromlu Bir Hastada \\ Herpes Zoster Oftalmikus
}

\begin{abstract}
Nilton Salles Rosa NETO, ${ }^{1}$ Luciana Feitosa MUNIZ, ${ }^{1}$ Luciana Parente COSTA, ${ }^{1}$ Manoel Tavares Neves JÚNIOR,
Licia Maria Henrique da MOTA, ${ }^{2}$ Jozélio Freire de CARVALHO${ }^{1}$

${ }^{1}$ Department of Rheumatology, Hospital das Clínicas da Faculdade de Medicina da Universidade de São Paulo, São Paulo, Brazil; ${ }^{2}$ Department of Rheumatology, Hospital Universitário de Brasília, Faculdade de Medicina, Universidade de Brasília, Brasília, Brazil
\end{abstract}

The varicella-zoster virus (VZV) is responsible for two infectious syndromes. Primo-infection generally occurs in infancy and manifests as varicella (chicken pox). Subsequent reactivation of the latent virus in the sensorial ganglia results in herpes zoster (HZ). ${ }^{[1]}$ The incidence of $\mathrm{HZ}$ in the general population ranges from 1.2- 4.8 cases per 1000 people in the United States ${ }^{[2]}$ and the incidence in SLE patients ranges from 3.2-43\%, ${ }^{[3-6]}$ $11 \%$ of which may be in a disseminated form. ${ }^{[2]}$ Among immunocompetent individuals, $10-25 \%$ may have herpes zoster ophthalmicus (HZO). ${ }^{[1,6]}$ There are few reports in the English language literature regarding patients with antiphospholipid syndrome (APS) who presented with VZV-related infections. ${ }^{[7,8]}$ Herein, we report the case of a patient with SLE and APS who presented with HZO.

A 25-year-old female was diagnosed with SLE in 2000. She also had prior cutaneous, hematological, articular, and serosal involvement along with antinuclear and anti-double stranded deoxyribonucleic acid (anti-dsDNA) antibodies. In 2005, the patient was diagnosed with APS after an episode of thrombophlebitis of the left saphenous vein that was associated with high titers of anticardiolipin immunoglobulin $\mathrm{M}$ (aCl $\mathrm{IgM})$ on two occasions (92 and $52 \mathrm{MPL}$ ) that were 12 weeks apart. The patient was on warfarin, chloroquine diphosphate $250 \mathrm{mg} /$ day, prednisone $5 \mathrm{mg} /$ day, and cyclosporine $100 \mathrm{mg} /$ day. There was no clinical evidence of disease activity, although there was evidence of inflammatory activity and consumption of complement. The patient presented with hemicranial cephalalgia that was refractory to analgesics but had no neurological deficits. After four days, vesicular lesions appeared in the region of the opthalmic branch of the right trigeminal nerve that were consistent with a diagnosis of HZO. Ocular involvement was verified by the evaluation of a specialist. At that time, the patient's leukocytes were $4430 / \mathrm{mm}^{3}$, and the lymphocytes were $1000 / \mathrm{mm}^{3}$. The patient was treated with intravenous acyclovir along with clindamycin due to a secondary infection. The amount of prednisone was increased, and carbamazepine was introduced. The patient recovered without sequelae and did not present with any new thrombotic phenomena after two years of outpatient follow-up.

There is a wide array of lesions that may appear in patients with HZO. The sclera and the episclera may be involved in addition to the cornea, and damaging forms of keratitis (e.g., punctata epithelial, dendritic, nummular, or neurotrophic) may appear. Other complications that have been reported are anterior

Received: April 9, 2012 Accepted: May 19, 2012

Correspondence: Jozélio Freire de Carvalho, M.D. Department of Rheumatology, Hospital das Clínicas da Faculdade de Medicina da Universidade de São Paulo, São Paulo, Brazil. Tel: 55-11-3061-7492 e-mail: jotafc@gmail.com

C2012 Turkish League Against Rheumatism. All rights reserved. 
uveitis, glaucoma, acute retinal necrosis, cataracts, optic neuritis, and paralysis of the oculomotor muscles. Some cases present with blepharitis and conjunctivis along with secondary eyelid infections that are usually caused by Staphylococcus aureus. ${ }^{[6]}$ It is also important to note the possibility of severe neurological complications, such as encephalitis and prolonged contralateral hemiplegia. ${ }^{[1]}$

The frequency of $\mathrm{HZ}$ infections in patients with lupus is elevated; however, it has not been previously reported in patients with APS. Rheumatologists should be attentive to the possibility of this occurring with the aim of promoting early and adequate treatment. In addition, it is necessary to take extreme care when monitoring patients, especially those expressing APA or those diagnosed with APS, after infection due to the risk of potential new thrombotic phenomena which might occur.

\section{Declaration of conflicting interests}

The authors declared no conflicts of interest with respect to the authorship and/or publication of this article.

\section{Funding}

The authors received grants from the Federico Foundation and CNPq.

\section{REFERENCES}

1. Liesegang TJ. Herpes zoster ophthalmicus natural history, risk factors, clinical presentation, and morbidity. Ophthalmology 2008;115:S3-12.

2. Schmader KE, Dworkin RH. Natural history and treatment of herpes zoster. J Pain 2008;9:S3-9.

3. Park HB, Kim KC, Park JH, Kang TY, Lee HS, Kim TH, et al. Association of reduced CD4 T cell responses specific to varicella zoster virus with high incidence of herpes zoster in patients with systemic lupus erythematosus. J Rheumatol 2004;31:2151-5.

4. Nagasawa K, Yamauchi Y, Tada Y, Kusaba T, Niho Y, Yoshikawa H. High incidence of herpes zoster in patients with systemic lupus erythematosus: an immunological analysis. Ann Rheum Dis 1990;49:630-3.

5. Moutsopoulos HM, Gallagher JD, Decker JL, Steinberg AD. Herpes zoster in patients with systemic lupus erythematosus. Arthritis Rheum 1978;21:798-802.

6. Shaikh S, Ta CN. Evaluation and management of herpes zoster ophthalmicus. Am Fam Physician 2002;66:1723-30.

7. Yilmaz MI, Koc B, Kantarcioglu M, Akinci SB, Ayta H, Bulucu F, et al. Pulmonary alveolar microlithiasis after Varicella zoster infection in a patient presenting with antiphospholipid syndrome and discoid lupus. Rheumatol Int 2002;22:213-5.

8. Uthman I, Taher A, Khalil I. Hughes syndrome associated with varicella infection. Rheumatol Int 2001;20:167-8. 